\title{
Creative Writers and Human Behaviour: An Evaluation of Rems Umeasiegbu's The Inevitable Aftermath and End of the Road
}

\author{
Florence. O. Orabueze, \\ Aloysius Orjinta \\ and \\ Ngozi Ezenwa-Ohaeto \\ DOI: http://dx.doi.org/10.4314/ujah.v14i1.3
}

\section{Abstract}

The debate on the environment and heredity as the causes of human behaviour is not restricted to the psychologists alone. Prior to the developments in psychology, which is a relatively new science of mental process and behaviour, the creative writers have had interest in the sources of the behaviour of their fictive characters, which are people portrayed in the worlds of their literary texts. This research, therefore, seeks to prove that creative writers have knowledge of the sources of human behaviour by using Rems Umeasiegbu's The Inevitable Aftermath and End of the Road to explore the potentiality of the environment and heredity, particularly the environment, as the driving force in the behaviour of youthful, fictive characters in the two novels. The finding is that the destruction of their relationships, whether marriage or friendship, leads to their development of psychopathological disorders, when their defence mechanisms have bulked under the overwhelming tensions from their environment.

\section{Introduction}

Psychology has been defined as the science of mental processes and behaviour. To Ronald Smith, it is the "study of behaviour and its causes" (1993:4). And to Gillian Butler and 
Freda Magus, psychology is the way "organisms, usually people use their mental abilities, or mind to operate in the world around them" (2008:2). Myers also calls it the science of behaviour and mental life (1989). One thing, therefore, stands out in all these definitions of psychology: it is the study of human behaviour. However, one cannot seriously talk about the human behaviour without looking at its causes. In other words, how much does the environment or nurture and heredity or nature influence an individual's behaviour (Mowbray and Rodger 276).

In psychology, different schools of thought or perspectives have different views on the causes of human behaviour. According to the biological school, physiological or genetic factors influence human behaviour. This school argues that heredity or nature does not only predict eye or skin colour, but is also a determinant of an individual's intelligence, sexual orientation, personality and aggression. In Scarr's argument, the environment cannot change genotype, that is, our specific genetic structure, but it does interact with it to produce changes in behaviour (1992). To further buttress this view, McGuffin goes on to argue that there is glaring evidence of genetic or heredity contributions to several categories of mental and personality disorders (1993).

To the psychodynamic school of psychology championed by the Austrian psychiatrist, Sigmund Freud, the causes of human behaviour ought to be sought in the intrapsychic factors, which include repressed childhood traumatic experiences and unconscious processes and motivations. However, to the cognitive school, human behaviour is rooted in dysfunctional and irrational pattern of thought. On the other hand, the radical behaviourists suggest that inner or biological factors do not shape human behaviour, but environmental factors and past experiences. In B.F Skinner's opinion, "A person does not act upon the world, the 
world acts upon him" (1977:211). This position is earlier emphasized by John Watson, who argues:

Give me a dozen healthy infants, well-formed, and my own specialized world to bring them up and I'll guarantee you that you take any one of them at random and train them to become any time of specialist I might select - doctor, lawyer, artist, merchant-chief and yes, even beggar-man and thief- regardless of his talents, penchants, tendencies, abilities, vocations and race of his ancestors (20).

The humanistic perspective, however, discards the determinate assumptions of psychoanalysis and behaviourism as it stresses the role of unconscious motives and freedom on human nature and human behaviour. It also argues that there is an active force in every human being towards growth and selfactualization.

Most psychologists have reconciled the five perspectives as they argued that to unravel the causes of human behaviour, the five perspectives complement one another. For instance, Robert Feldman suggests that environmental factors play critical role in enabling people to reach their potential capabilities that their genetic background makes possible (2000). And Ronald Smith puts it forcefully that "the prevailing view today is that genetic factors create a range of possibilities within which environmental factors operate to positively or negatively affect characteristics and behaviours" (1993:97). In other words, nature and nurture complement each other as the sources of human behaviour.

There is no doubt that the novels under discussion- The Inevitable Aftermath and End of the Road -that Rems 
Umeasiegbu, like other creative writers, uses the "application of scientific evolutionary methods on human phenomenon" (Akwanya, 2004:156) either consciously or unconsciously. Nature and nurture or heredity and environment manifest themselves in the form of culture that break the relationship of the fictive characters that inhabit the worlds of the novels.

Culture has been understood as a "total way of life" (Williams 10), and Clyde Kluckhohn goes a step further to describe it as the "total way of life of a people, the social legacy the individual acquires" (1949:20). Tylor itemizes the social legacy to include "knowledge, beliefs, arts, morals, law, customs, any other capabilities and habits acquired by a member of society" (1958:10). In Leo Nnoli's "The Role of History and Culture in Promoting Good Governance", he states that culture "represents the totality of people's way of life, those social elements that include food, art objects, traditions, norms, mores, customs and values for which a society is particularly distinguished. Divided into two major components, culture could be material or non-material. The first being the instruments and products of man's labour, while the second constitutes the ideas of man" (2012:246). Interestingly, James Curtis argues that culture is not only a shared definition that influences behaviour, effect and cause of behaviour, "but also people in interaction develop culture, they alter it, they preserve it, they transmit it, and they are guided by it" (1981:34).

In The Inevitable Aftermath and End of the Road, culture as a group of people's mores, norms or values that are transmittable and preservable manifests itself in two formsracism and sexual intercourse. Simply put, racism is the belief in the inequality of races propounded by such hegemonic Western philosophers like Hegel, David Hume and Immanuel Kant. Martin Barker argues that racism is "part of our biology and our instinct to defend our way of life, traditions and customs against outsiders not because these outsiders are 
inferior, but because they belong to other cultures" (1981:78). Attitudes or practices are said to be racist if they are "oriented in intention or effect towards the production, reproduction and affirmation of unequal relations" (William 190), and to Goldberg, racism is not about dominance but about exclusion and otherness (1993).

Furthermore, in The End of the Road, sex is the pervasive norm in the setting of the novel. And sex is defined as the "sum of the peculiarities of structure and function that distinguish a male from a female organism; gender; sexual intercourse and sexual relations" (Black's Law Dictionary 1498). The way this human desire is presented in the novel, it is not a means of gender distinction, but as sexual intercourse which has been defined further by The New International Comprehensive Dictionary of the English Language as the "sexual act, especially between humans, in which the erect penis is introduced into the vagina for the ejaculation of semen and sexual gratification. Any act of sexual connection, especially between humans" (2010:1153). Philosophers and psychologists suggest the communicative and affective role of sex in human relationship, which lifts it above the instinctive sexual drive of lower animals. Dwyer argues that sex offers self-transcendence and liberation from egoism. And that sexual love awakens the feeling of wanting to give and of wanting to please, of wanting to give of oneself wholly and entirely, without reserve and without calculation (1987). And Paul Ricoeur's earlier opinion before Dwyer is that sex is a language, which expresses tenderness (1964).

This study posits that creative writers reflect that nature or heredity and nurture or environment are the sources of behaviour of fictive characters in works of literature. Though what literature is has been an object of contestation from the time of Plato, the first known critic of art. To some critics, 
literature is not about human condition and human experience, but it is autonomous of external conditions. Such critics argue that what gives literature its literariness is its language, for it is "art which imitates by means of language" (Aristotle 5), and what A.N Akwanya calls "thought-made-object" (Language and Habit of Thought 112), Chibuzo Onunkwo sums up the position of this school of thought as "Language which is profound, enigmatic and symbolic in nature. Literature is where one encounters a language whose mode of being is literary" (2009:40). On the contrary, there are still critics who insist on the communicative value of literature. It "indeed mirrors the society and presents the reflection for the same society to either commend or condemn" (Amodu, 2013:122). And Wole Soyinka argues that literature as a mirror must expose, reflect and indeed magnify the decadent, rotted underbelly of a society that has lost its direction (1958).

It is submitted that in the two novels under evaluation The Inevitable Aftermath and End of the Road - Rems Umeaiegbu is not much interested in the literary language of his works, but in the exposure of a society's over-emphasis on the culture of racism and sexual intercourse, which destroy the relationship of its youthful members, and give them psychopathological disorders. This research simply joins the ongoing discussion on the issues raised in psychology that the causes of human behaviour can be found in nature and nurture and creative writers have always shown this awareness as is reflected in their fictive characters. For instance, Tom Morrison's novel, Beloved, was published in 1987, and it explored the collective memory of slavery, which was predicated on racism. In her criticism of the novel, Jan Campbell historicizes psychoanalysis. She argues that Beloved, which is the ghost that haunts every occupant of 124 Bluestone House, should not be read as the "return of the repressed but psychic forgetting or amnesia which represents the destruction of the internalized (generative) maternal object, 
or beloved within the self. She also represents the psychic forgetting as destruction of the facts of slavery, which no one wants to remember" (2013:145). Again in Ralph Ellison's critical study of Richard Wright's Black Boy, he states that the novel is not only an autobiographical chronicle of personal catastrophe expressed lyrically, but it is also the exposure of the agony and confusion of the slaves and the relationship between the white and the black people (1953). Apartheid is also an officially-sanctioned policy of segregation of the races in South Africa. In Mkhize's analysis of Alex La Guma's $A$ Walk in the Night, he suggests it is a naturalistic novel that details the social problems, which the coloured people of South Africa are subjected to by the inhuman apartheid system (1998).

Besides, through the reading of the Congolese author, Sony Labou Tansi's Je soussigne cardiaque, Julia Everett explores the potential of queerness, specifically homoeroticism and slippages between masculine and feminine persona, as a driving force within African post-colonial literature (2013). Also the recurring characterization of the traditional or rural women as a childlike subject lacking focus in literature has been criticized. Molara Ogundipe-Leslie condemns the depiction of the African woman as one who is "submissive and unable to comprehend modern technological advances" (1994:50). Chijioke Uwasomba continues with her line of argument when he suggests that the Nigerian woman has been represented as a butt of repressive patriarchal structure that reduces her human essence and dignity. He further argues in his "Flora Nwapa and the Burden of the Nigerian Woman" that she has been "conditional to think and believe that she is inferior to the men and must submit herself to the whims and caprices of the man, willy-nilly" (2009:124). But such inferiorizing of women, Ilesanmi believes, is a product of 
myths created to "explain not only the natural order or reality but also the cultural practices of man in order to justify and legitimize" (1998:30-31) such myths. Marcellus Onwuegbuchunam and Loyce Chinenye Okoye state that gender equality is an indication of good governance. Conversely, they argue, "Exclusion of the majority (including women) from participating in politics and the development process" (2012:797) is a hallmark of undemocratic governance.

There is also enunciation of the roles of the environment in forestalling ethno-religious conflict in multilingual nations like Nigeria. It is obvious that the environment is not only the cause and effect of behaviour, but it is also a prerequisite in effective human relations. It is argued that if safe environments that nurture each individual is created, and he is emotionally, spiritually and intellectually balanced, effective human relation would be maintained at all levels (Udezo and Nwadialor 2013). It ought to be an environment that "supports a secular and tolerant society in combination with individual possibilities for commitment and choice" (Goring, et al, 2012:219).

It is obvious from these literature reviews that none of them has dealt precisely with issues raised in this research. However, this study intends to use library and internet research to prove that Rems Umeasiegbu's novels- The Inevitable Aftermath and End of the Road-show evidence of the creative writer's awareness of the causes of human behaviour as arising from both nature or heredity and nurture or environment. Rems Umeasiegbu, particularly, elevates nurture or environment over and above nature or heredity. It is obvious from the readings of the novels that he believes one is born pure, but environmental factors, particularly the culture of racism and sexual intercourse around one, decides whether one would be in a stable relationship or not, and whether one would suffer from any of the psychopathological disorders or not. But first 
of all, the novels would be summarized for clarity and a better understanding of the nature-nurture factors that motivate the characters.

In The Inevitable Aftermath, the events narrated happened in colonial and post-colonial Aguoka and in England and Germany, where a young black student flirts with several uneducated and half-educated, young and naive white girls, before settling down with one of them. Tina Brown, an English stenographer marries Oji Egboka, a young Aguoka student in England. Both of them are aware of the culture of racism and other barriers that are antagonistic to their mixed marriage, but they are ready to defy them and live their lives as a happy couple. However, when Oji finishes his post-graduate studies, he has to return home with his white wife, after seven years in London. His family and his community are shocked and disappointed that he is already married to a white woman. But Oji is desirous of reintegrating himself with his society and their world-view. When Tina can no longer find the situation bearable, she decides to abandon the marriage to return to England. The novel ends with hope for the survival of the marriage, for while fate delays the takeoff of Tina's flight, she hears over the radio at the airport that her husband has an accident and is critically ill in hospital and she goes to see him there.

Meanwhile, the events narrated in End of the Road occurred at Amesi State University. The narrator portrays a state, a family and a university whose activities are pervaded by sexual intercourse. The state is presented as a dysfunctional one where the leaders are corrupt and the basic infrastructure needed to run a university are lacking. Their priority is to give inflated contracts to women who cannot execute them; yet, they collect bribes in cash or in kind from the female contractors. At the family level, the narrator presents a picture 
of irresponsible parents whose interest is in money-making, sex and other material things at the detriment of their children, who grow up on their own. The students are also left in the care of wolfish lecturers who are disillusioned and see the girls as part of their fringe benefits and the reason for staying in a frustrating environment. The love relationship of two campus students, Amon and Shaga, who are unfaithful to each other, turns dangerous, when Amon's room-mate, Ngoo, snatches Shaga from her. The novel ends with the death of the two girls in their bitter and violent fight to possess Shaga.

\section{Heredity and Environment: the Determinants of Characters' Behaviour in the Novels}

In The Inevitable Aftermath, we are presented with the culture of racism and sexual intercourse. From the very first page, the reader is presented with a marriage on the brink of collapse. With a flashback, the events that brought about the inter-racial marriage between Oji Egboka and Tina Brown despite the differences in their cultural world-views are narrated. Oji Egboka as a student in London is presented as a sex-maniac, who runs after naive and young white girls from the lower English society. He is expelled from Colonial House in London because he protests with other black students when his girlfriend, May, is fired from her job because of the scandalous relationship she keeps with a black student, Oji. Oji haunts down one white girl after another that when his property is cleaned out by one of the girls he brought to his room, he cannot complain to the police, and because of his reputation as a sex-addict, "no one would help: after all, even his landlady has started to complain about the number of white female visitors he had weekly" (108).

One would naturally wonder what the problem is with Oji Egboka, while in London, because as at the time he is in Aguoka, he is still a virgin at twenty-two years. Is it possible that his sudden change from being a virgin to being a sex- 
maniac that sleeps with every white girl that is trapped in his web as a result of a genetic blueprint that unfolds with time? His father, Mazi Egboka, is not presented as a sex-maniac or as a polygamist, though Oji is his only son. But a close reading of the novel reveals that this is Oji's unconscious reaction to the racist culture in his new environment, London. In the university, the black students are kept at Colonial House, which he calls a racist camp and he suspects that they are being spied on. In fact, racism has the stamp of officialdom as he is denied admission to study for his postgraduate degree at Wetschmerz, which may also be interpreted as his lack of good character, because May complains that he extorts seventy pounds from her to buy the Austin Mini Cooper. Also the police that caught him for traffic offence set him free because they are satisfied that he is about leaving the country and that the white woman with him is French and not English, which, of course, are all lies. White people who come to help Tina when their car broke down drive away immediately they see Oji. In the bus, he is also snubbed and ignored. Tina's parents are angry that she is dating a black man. Her father is so angry that he assaults Tina, disowns her and never attends her wedding. In Germany, he also goes through the same horrible and terrifying experience that he and Tina who went on Christmas vacation are denied accommodation in hotels because he is a black man. An old German is so infuriated when Tina and Oji are kissing that he warns him, "How unfortunate Hitler lost the war! You would not be in Deutschland in the first place not to talk about going around kissing a Deutsch girl" (114). He also suspects that Dr Zimmerman's abortion on Tina, which makes her unable to conceive latter, is as a result of racism. And this raises the issue of medical negligence which is described by a legal jurist as "... a breach of a legal duty to take care which results in 
damage to the claimant. Medical negligence is, therefore, a breach of a duty of care by a person in the medical profession, to a patient, which results in damage to the patient" (Ifeoma Enemo, 112). However, the young generation of both English and German people are more accommodating of other races. Tina is proud of Oji and loves him exceedingly and does not see anything wrong about the difference in their races. This is also the case in East Germany where the men appeared to be more reserved than the women but, "Wherever they went, East German girls had shown interest in them. They paraded Alexander Platz in the most fashionable parts of the city- hand in hand with no sign of hostility. Rather, the girls showed interest and envied Tina" (119).

It seems that Oji Egboka uses sexual intercourse as an instrument of revenge against the white people's domination and colonization of Aguoka. He appreciates the sexual superiority he holds over the white male, who is in physical occupation of his fatherland. The white female's body becomes the battleground for the contestation of the superiority of the races. It seems the white men accept the sexual domination of the black men over them. Mr Leghorn lectures Tina, "You must be careful you don't get involved with the men.... African men are sex maniacs. They don't mind raping European women and spending the rest of their lives in jail" (129). His statement is right, as Oji Egboka sees the white woman's body as a site to encounter and dominate the white men who rape the continent and its women. To him, there is no question of morality in using the white girls because, "we're paying them back in their own coin" (53). Tina's mother recognizes Oji's domination over the husband, when he scolds her for encouraging Tina's relationship with Oji. She tells him, "Here was a foreigner courting your only daughter in your own house and instead of facing him you decided to run away. Please don't let me get annoyed. Why were you in hiding" $(81)$ ? 
But racism is not a one-way traffic but two; Oji's people in Aguoka also reciprocate the English with their own racial prejudice. Right from the Aching Port when the ship docks, a young customs officer eyes the couple mischievously with a look that may be read as, "I don't blame you for marrying a beautiful white woman but it is still a misdemeanour all the same" (134). His parents, Adaku, whom his parents have married for him by proxy and the entire Aguoka Improvement Union that have trooped to the Aching Port in a celebratory mood to receive him turn their back in disappointment when he arrives with a white woman by his side. His people feel that by his marriage to a white woman, he has rejected his parents, his family, his people and the principle of "Omenanaism". In return, they reject him. His father's stubborn stance on not paying the sanction imposed on him for Oji's abominable act leads to Oji's mother's death. He has to stay in a hotel with Tina for several weeks; he cannot get a job and his political ambition is stalled and the educated people also reject his inter-racial marriage. Even the dead mother's wraith visits Tina in his house and smiles condescendingly at her.

Though Tina and Oji defy all the odds and make a lot of sacrifices for the survival of their marriage, there are always hiccups in their relationship. For instance, the novel begins with a disagreement between them as Oji complains of the scrambled eggs Tina wants to serve him for breakfast. He queries her, "Why the hell can't I have fried plantains" (1)? The difference in the menu of both races is obvious even when they were in London. Oji is aware that the English drink a lot of tea and he accommodates that and pretends to enjoy it. He also knows that during courtship, Tina is a pampered daughter and tells him that she does not know how to cook, and he is willing to do the cooking as they both erroneously think that it 
is only sex and love that are involved in marriage. It is with Aguoka menu of egusi soup that Georgina, his secretary in the office, whom the narrator calls a "killer", attempts to seduce him. He confesses that he has not eaten egusi soup for a long time, and she admonishes him, "You prefer potatoes and you are getting them" (15). Oji fantasizes, "How wonderful it would be to have an understanding wife like you" (15).

Another material difference in their culture is the structure of the family. The presumption in both English and Aguoka culture is that the father is the head of the family. However, for the English family, this seems to be a mirage. Tina seems not to bother about her father's opinion about her relationship with a black man. To her, she is free to do whatever she wants to do - go into marriage with anyone she fancies, and leaves for Africa without her father's consent. This is not the same in Aguoka that operates a system of communalism, unlike the English individualism. Marriage is not a private affair in Aguoka and that is why the head of Egboka's family, Chief Egboka, is sanctioned for the abomination the son committed in marrying a white woman, irrespective of the fact that Adaeze has been married for him by his parents. Though Oji's father in his stubbornness refuses to pay the fine, and he argues that he cannot pay for his son's wrongdoings. He later agrees to pay the fine when he realizes that one is not greater than one's community. One other thing he fails to see in the sanction his community imposes on him is that as long as he is alive, his son, though married with his own family, is still under his authority. And this is the reason why Oji has to cancel the order he has placed to buy Tina a car and he "then signed a check for $€ 200$ his father had asked for" (10).

Besides, both races detest inter-racial marriages, but while English marriage is compulsorily a monogamous one, Aguoka culture sanctions both monogamy and polygamy. The principal of the grammar school in Ames, where Tina teaches 
English language to form one students, has a master's degree from an American university. Despite his level of education, he is married to two illiterate women. Oji intends to have a monogamous marriage but Tina's childlessness may force him to marry another wife. Seven months after Oji and Tina come back to Aguoka, she has not conceived, and Mazi Egboka is worried about the situation because her inability to conceive means the end of his lineage, since Oji is his only son. Childlessness is detested in every society; May's marriage is broken because of her barrenness; in Aguoka, bareness is "like the terrible disease of leprosy which is never called by its proper name but is rather given a euphemistic name and called the white man's disease" (145). His father gives him an ultimatum that he has only six months to make up his mind to marry another wife. But before his father makes clear his position to him and while still in London, Oji has decided that if Tina cannot conceive because of the abortion he persuades her to have, he would definitely remarry as he reasons, "A man without a child was like a weed devouring the manure provided for vegetables and cash crops and unless the weed was removed, the vegetables would surely be stifled" (127).

In End of the Road, Rems Umeasiegbu presents an environment - a state, a university and a family - that is preoccupied with mundane things. In other words, the novelist presents a society that is engrossed with the culture of sexual intercourse: a society that breaths, speaks and thinks of sex. At the level of governance in the state, leaders like Chief Showola, who is the secretary to the government, prefers awarding inflated contracts to his women-friends, whom he knows quite well are incapable of executing them. Instead of the government providing basic infrastructure in lecturerooms, where there are not enough seats for students and the "non-existence of ceiling fans worsened the situation" (9), 
Chief Showola prefers to give a contract of a quarter of a million naira in order to receive cash rewards from the female contractors and to also make "sure he was sexually intimate with both the contractor and her daughter or daughters" (87). The commissioner of police in Dexter who represents law and order is also implicated in this culture of sexual intercourse. He fails in his duty in the prosecution of the fight between Amon and Professor Etunkobo's wife that leads to the latter's miscarriage, because he is a "one-time lover of Amon's mother" (84).

When the state fails in its duty to fund university education, both Dexter University and Amesi State University become places where sex is sold and purchased. For instance, Amesi State University's classroom is presented as a place where "odour of cohabitation pervaded the entire place" (9), and in Princess Natasha Hall, Amon "saw a condom, bloated with human venom, lying carelessly, on the hallway" (52). Umeasiegbu holds the mirror for the society that is not serious about its educational system. The lecturers who are frustrated with their meagre salaries and lack of research funds take solace in the accommodation they are provided with on campus and the female undergraduates, whom they sexually harass, as part of their fringe benefits. Without any serious pursuit of academic excellence, the lecturers spend their time on the female students and their businesses. Professor Hencock, with his symbolic name that evokes the imagery of cohabitation, is a man who is separated from his wife. He is described by the narrator as running a "consultancy service, owned a provision store and a printing establishment and conducted feasibility studies for four state governments" (13). It is obvious that the professor is more of a trader than an academic. When serious-minded students in his class complain to the vice chancellor about his incoherence and obscenity, he tells them that, "Amesi State University was synonymous with Professor Hencock" (14). With this type of administrator, it is 
not surprising that a crook and a fraudulent womanizer like the senior lecturer, Isidore Ishiagu, who initiates the students into hard drugs, sexual promiscuity and alcoholism in his wild parties, is never expelled.

When the lecturers cannot provide good mentorship for their students, the latter get involved in sexual orgies. Academic works are relegated to the background as the students $a b$ initio gain admissions into the university through examination malpractices, and they ensure their graduation through sleeping around with the male lecturers. But then, no one can blame them, since they have mundane motives for coming into the university. Ngoo's reason for coming to Amesi State University is to date a handsome man like Shaga, and when she is able to snatch him from her room-mate, Amon, she is ready to die instead of letting him go. In fact, Ngoo is not alone in her reason for university education. The narrator reveals that Amon who is in Dexter University before her sex scandal is there, "because every other friend of hers was entering a university" (82). As one of the girls explains to a serious-minded professor who is intent on teaching them that they are not interested in his profound ideas. Another explains to him further that "their reason for being there is for the boys, to attain salary grade level 08, and the girls to get real cats. Puzzled about cats, he had been told that cat is for man, as girls is for cocaine" (83). With this outlook in life, the students show profound interest in sex and that is the reason for their over-riding interest in Professor Hencock's course. As the narrator puts it clearly:

Soc 205 was a most popular course at Amesi State University. It was meant for juniors in the department of sociology - twenty-nine students all together. But students of anthropology, 
music, education, psychology, drama, folklore, African studies and mass communication found it useful and registered for it. A few others who could not register for it had to audit it... rumour had it that Professor Hencock made sex appear so easy that Johnson and Masters would be amazed (12-13).

So apart from this course which they attend en masse, they enjoy being given a lecture free day on Friday and at weekends, their libraries and hostels are deserted as they travel out to stay with their lovers outside or in the campus.

The family is another social institution that has failed the youths in the world of the novel. No one is surprised at Amon's sexual escapades at Dexter University and Amesi State University with the type of family background she has. Her family is one of the environmental factors that influence her lifestyle of sexual gratification. She comes from a dysfunctional family where the emphasis is on sex and materialism. Her father, Architect Jokodola, is not the best family head; a man who goes out anytime he likes without telling his wife his whereabouts. He is presented as an irresponsible man who "abandons his house without any provision whatsoever made for them" (72)? Her mother too is presented in a manner that is shocking. She is not only going out with men, but she allows them to sleep in her matrimonial home in the presence of her daughter and grand-daughter, Meg. She is also ready to give out Amon to Chief Showola as long as she can get contracts from him. In fact, Amon, who sleeps with three different men in less than two days and feels no qualms about her action, would not have done otherwise. Her family background becomes a motivating factor for her behaviour; the traumas of her childhood stick to her like a second skin. The narrator emphasises thus: 
Like the day she caught her father making love to Auntie Isanwan. Auntie Isanwan was her mother's younger sister. Mrs Jokodola never knew of this, but the shocked rage still lingered in the memory of Amon. Or like the day she caught her mother kissing a man the family did not know.... She often wondered if Mr Jokodola was in fact her biological father. As she attained adolescence, she noticed with concern that her parents sought and obtained marital relations outside the family. One of her father's girlfriends was her friend in secondary school. Her mother, Mrs Jokodola, had once snatched a boyfriend from her (72-73).

With this type of immoral parents, it is not out of the way that she gets pregnant outside wedlock as a teenager, but now she has grown up and sleeps around with men, she carries diaphragms in order to avoid unwanted pregnancies. But the reader is told that $\mathrm{Mr}$ and Mrs Jokodola are not exceptions to the rule. In fact, the narrator states that "Both parents are rotten, in terms of morality, but most couples she knew were like $\mathrm{Mr}$ and Mrs Jokodola. Some were even worse" (73)! Therefore, it is not surprising that almost all the students male and female - in both Dexter University and Amesi State University are involved in a promiscuous sexual lifestyle.

\section{Defence Mechanisms of the Characters in the Novels}

In the personality structure of an individual, according to Sigmund Freud and the other psychoanalysts, when the ego is under threat, it has succour in defence mechanisms in order not to break. And they are believed to be aspects of egofunctioning that occurs at an unconscious level. The most basic 
defence mehanism is repression, which is described as motivated forgetting of anxiety- arousing memories or feelings or impulses from getting into consciousness. Reuben Osborn, quoting Sigmund Freud, said that repression is the "psychological equivalent of the process in the body which a protective wall of tissue isolates a diseased part from the rest of the body" (1965:4). Interestingly, though the childhood traumatic memories and experiences are repressed, they continue to exert an important influence on the actions and thoughts of the victims. The second defence mechanism is displacement in which an unacceptable or dangerous impulse is repressed, and then directed at a safer substitute.

As this research has consistently argued, it is not only the psychologist or the psychiatrist who has an idea of the causes of human behaviour and the defence mechanisms, which individuals employ, when they are faced with tension or conflict or anxiety-arousing situations. Creative writers also use these defence mechanisms in the delineation of the psychological makeup of their fictive characters in the face of conflicts. For instance, displacement and repression are the two most important defence mechanisms, which Rems Umeasiegbu appropriates to ensure that his fictive characters do not develop psychopathological disorders, when they are faced with conflicts from environmental factors in the two novels.

In The Inevitable Aftermath, it seems that in Aguoka that Oji Egboka has repressed in his unconscious the racism that goes with colonization, which "exploits a colonial people and their natural resources without any responsibility accruing as a result of this privilege" (100). In other words, while living among his people in Aguoka, he does not feel the impact of racism much; nevertheless, it is repressed in his unconscious. When he comes to England to study, he confronts the brutal crushing machine of racial prejudice where he cannot be served in a restaurant by waiters and waitresses because of the 
colour of his skin, where he cannot lodge in a hotel because of his skin pigmentation, where he is denied assistance to repair his vehicle because he is a black man, and where he is isolated in a bus or train because of his race. He studies and understands the system, using lies, his brilliance and suave disposition, to survive the environment, which before he left, he has "developed a virulent hatred for the Caucasian race" (125), which he must find a safe way to discharge through the defence mechanism of displacement. He explains his sexual exploitation of naive white girls without caring for their feelings and recompense, because, "If I were studying in South Africa or the United States of America, countries where racism is institutionalized, I would knock the girls hard. Mind you, white girls, not black ones"(100). His sexual exploitation of the girls, therefore, becomes a safe method of displacing his unacceptable repressed impulse on a people who subject him and his race to humiliating treatment and exploit the natural resources of his fatherland. Without displacement, the narrator reveals what he would have done, because:

Each time he saw a white person (women expected) he felt an upsurge of the destructive instinct in him. It was a violent reaction not unlike the stampede that takes place when a cinema hall catches fire. If he was to remain in the country for the rest of his life he would definitely end up in a psychiatric hospital. He realized this fact more than anyone else and never regretted his departure. When asked by some white friends who had come to see them off what he would miss most, Oji has replied, "English racism" (125). 
Also in the End of the Road, Umeasiegbu portrays a horrifying environment that destroys the lives of its youthful members. He presents two characters - Amon Jokodola and Isidore Isiagu - whose repressed childhood traumatic experiences motivate their actions even in their adult lives. The narrator presents Isidore Isiagu as an irresponsible and an unmarried lecturer. He is a self-made man, who stows away to England at eighteen years and is doing menial jobs there, without going to school. He exploits the English girls sexually, and in a country that is vigilant and protective of its youths, he is deported from the country. He finally gets to the United States, where he reads "black thoughts and letters and later, comparative literature" (33). He is employed by Amesi State University and a senior lecturer, but despite his age and position, he is a pimp, who recruits male and female students and initiates them into promiscuous sexual intercourse, alcoholism and drug addiction. He is very irresponsible that he sleeps with girls in secondary school and also snatches girlfriends from their boyfriends. But Umeasiegbu does not hesitate to reveal to the reader that the character's traumatic childhood experience, which presumably repressed in his unconscious, still exerts influence on his thoughts and actions as an adult. As the narrator states:

As he got older, he found himself becoming more and more addicted to women, if one could be said to be addicted to them. In this matter of addiction, he was just a chip of the old block. His father had five wives and was planning to marry a sixth before he died. His appetite was prodigious and catholic. Little wonder he died of V.D. He was always quarrelling with Isidore's mother, calling her all sorts of names. 
The young Isidore grew up with these scars (33).

Furthermore, Amon Jokodola is another fictive character who is haunted by her repressed childhood traumatic experiences. Not only that she grows up in a home, where the parents fight, but they are also presented as being sexually immoral. The shock and rage of seeing her father making love to her aunt, and seeing her mother kissing another man still lingered in her memory, but the worst of her repressed traumatic experiences is:

Like the day several years ago, the father castigated the mother for not terminating the pregnancy that brought her into the world. The way Amon understood them was that she was an unwanted child, a child forced on them. That trauma had remained with her since that day, repression or no repression (72).

The repressed traumas that she is an unwanted child, and the orgies of sexual intercourse she witnesses in the family, at school and in the society propel her to be a sex maniac. The result is that she has a child as a teenager; at Dexter University she is involved in a sex scandal that leads to her withdrawal from the university, and at Amesi State University, she is involved in an amorous rivalry that culminates in her death and that of her room-mate, Ngoo.

\section{Psychopathological Disorders of Characters in the Novels}

The novelist shows in the two texts that there are consequences or abnormal behaviour or psychopathological disorders that invariably accompany the destruction of a character's defence 
mechanisms of the ego by either repressed and traumatic experiences or from the relentless energy from the id or from the overbearing super-ego. Like it has been argued earlier, the creative writers show their knowledge of the psychopathological disorders as a result of nature or heredity or environmentally-induced factors or nurture as reflected in the characters that inhabit the worlds of the novels.

Rems Umeasiegbu shows his awareness of the mental and personality disorders, which characters may develop as a result of the environmentally-induced stressors: the culture of racism in The Inevitable Aftermath and gross sexual intercourse in End of the Road. For instance, Oji and Tina's environments are very hostile to them, and because of that, they develop some psychopathological disorders as a result of racism. Oji who has been lectured by Father O'Neil on how to adjust to his new environment in London is oppressed by the rejection he experiences as a result of his race. Though he is a brilliant student, who makes a first class, bold, speaks fluent English and is polished that Mrs Brown, Tina's mother, has to admit to her racist husband, who is driven insane by the relationship of his daughter with Oji that "he looks so refined and polished" (81). But beneath his refined manners, he is haunted by the trauma of racism, that if he stayed longer, he would have committed murder. He never committed murder but displaces his repressed feeling, and sexually preys on young and naive English girls, who are not racists. The narrator presents Oji as a man who lacks moral integrity by his actions. He betrays May by his complicity with Cyrinus to rape her while she is drunk so that he can have the ground to end the relationship. He is presented thus, "Oji took a taxi home. He had thought it would be impossible for him to sleep but he slept very soundly - like a small child that had been denied sleep for three nights because of nightly spells of hiccoughs" (62). 
The same presentation is seen while Tina, whom he has persuaded to abort the baby she is carrying for him, and who is described with the simile of a "sheep being led to its death" (96) at Dr. Zimmerman's clinic. Oji who is outside with other patients at the hospital's waiting-room lies about Tina's relationship to a blond girl, whom "he told her how much he admired her"(97). Cyrinus, an ex-seminarian from Aguoka, who is studying medicine in England, feels that Oji has a split personality, because he "would act like a human being on one occasion and like a brute on another" (57). Despite his theological studies in the seminary, Cyrinus uses his Igbo worldview and superstition to describe Oji as an ogbanje for "how on earth could he behave so abnormally" (57). Oji has argued severally that his action is a form of retaliation for the colonizers' rape of Africa and African women but Cyrinus, who is used as his foil in the novel, still insists he has personality disorder as he queried him, "Tell me frankly, Oji, aren't you capable of loving a woman? I don't mean the type of wild and animal love you profess to and make to every girl that crosses your lair" (100)?

Though Cyrinus' question raises the issue of nature or heredity, an instinctual drive, as the prime motivator of Oji's sexual drive, particularly, as he tells Oji about the latest gossip at Colonial House is that "Africans... are imbued with an insatiable lust for sex" (101). It is obvious that Oji is capable of loving a woman, Tina, for when he earns some money from the publication of his book, he decides to turn a new leaf. He actually turns a new leaf for his attitude towards English girls changes, and he "was determined to show genuine love to his girlfriend, Tina" (110). His love for her remains unchanged despite his mother's death because of his inter-racial marriage, his ostracism, his childlessness despite the fact he is an only son. In Aguoka where such love is not displayed openly: 
Oji strode in with a bunch of flowers. The hug she gave him could give a casual observer the impression that the two lovers had not seen each other for years. Her head just stopped short at the tip of his neck. They stood there like two infatuated youngsters stealing a couple of kisses; their eyes filled with desire (4).

Though Oji still keeps his chain of mistresses in the city, though his secretary, Georgina, seduces him with food and shakes "her hips mischievously" (5) at him, "He always realized how much he loved Tina and how much she meant to him each time they quarrelled" (16). It is out of this love that he has a fatal accident while he is driving to the airport to ensure that Tina has not left the country. It is the same reciprocal love that defies their families and races that the novel ends with, "Tina was the first visitor he received as he lay in the hospital bed drinking blood copiously through the veins. She heard about the accident as a news flash through the airport radio" (159).

The same psychopathological disorder is seen in Tina, but to a minor extent. Tina is aware that her educational background is not comparable to Oji's. She is an English woman, the daughter of a publisher and a school teacher who lives in Essent, "a small village of less than eight thousand inhabitants" (74). She meets Oji in London. On the other hand, Oji is studying for his doctoral degree and if he is a white man, there is no way Tina would have been his girlfriend, to think of being his wife. But Oji has no choice but to date white girls from the lower class, which is the only option available to him, in a society that categorizes his race below that of domestic pets. But each of them is aware of the class divide between them, despite the differences in their race. Tina confesses to him at the beginning of their relationship, "I don't know why, Oji, but I feel so powerless in front of you. I've never felt like 
this before. Oji, I know I love you but.... But I am afraid" (65). Beyond the fear of Oji leaving her to go back to Aguoka, when he finishes his studies, there is the underlying fear of insecurity as seen in their holiday in Germany .She does not allow him to go out alone because other white girls show interest in him and "Tina seemed to have an inkling of what he has up his sleeves" (119). He is also aware of this class divide between them, for after the marriage, he reminisces, "Was the marriage necessary? Was it expedient for him (a candidate for the Ph.D) to marry a woman who had never sat in a university classroom" (121)? In Aguoka, the difference in their educational background comes up again when she wants to get job because, "Admittedly her education was not the type that would make a husband optimistic about finding a job for a wife" (149). And even Adaku his parents marry for him at Aguoka has a better educational qualification than Tina.

With the differences in their educational background, differences in their race, differences in their worldviews and linguistic differences, Tina develops a phobic disorder, particularly when she lives with him in Aguoka. Despite the fact that she has been reading works on Aguoka, which would help her adjust to life there, when they finally leave for home, "She was shivering with fright.... what if Oji's parents rejected her? Suppose his parents had married another girl for him according to their law and custom" (131)? Indeed, she thinks of what will happen while S.S Takoradi is on the high sea sailing to Aching Port in Aguoka and that is exactly what happened. It is not only that Oji's parents marry Adaku for him, and that his parents reject them, but the whole community also rejects them. As the narrator puts it:

Perhaps the immediate relations of Oji were to blame; perhaps not. But the sight of a son of the 
land telling them he no longer belonged to them by marrying a white woman was a blow too severe to tolerate while lying down. He embraced his parents but the warmth was not there (135).

Tina who watches the episode at the port "was dazed. She saw her world shattered and torn asunder"(136). She tries as much as possible to gain the people's acceptance. She learns how to speak Pidgin English, allows Oji to bring his niece, Mabel, to live with them in the house and also for Oji to pay his two cousins' school fees. Despite all her efforts to accommodate the communalism of his people, she is still haunted by her inability to conceive. The language barrier involved in interracial marriage also pushes the marriage to the brink. The conversation between $\mathrm{Oji}$ and his father on the necessity for the continuation of the Egboka linage is in their vernacular language that:

Her smattering knowledge of the native language was insufficient for her to make any meaning out of the intricate weaving of words carried out by her father-in-law. She, nevertheless, understood that the conversation was hinged on her. In her disgust, she had gone into another room in order to forget the "dangerous" alliance she felt was being formed against her (146-147).

After Oji's conversation with the father, she tells him, "I am depressed, honey" (147).

The novelist consistently delineates her phobia and subjects nature to her mood. When she quarrels with Oji, the narrator uses the natural elements to offset that mood, because 
"For her, the sun was already beginning to set. The morning had looked so promising when she woke up but now night had overtaken the day" (1-2). Not only that lilac rings form underneath her eyelids, she does look older than twenty-five years. Her reflection on the mirror "was that of a haggard woman in her late thirties" (2). Her mood swings into a happy one again when Oji phones her, apologizes to her and is coming home with a bunch of flowers. The narrator also uses nature to reflect that happy mood:

A rushed titivation followed and all was set for her husband's arrival. The sun, in its crescive coat, was now taking over the guardianship of the sky's vault and its piercing rays gate-crashed into many homes. Tina was glad that the day had brightened more than she thought. Prior to the telephone conversation with her husband, she had considered the day lost and forgotten (4)

The reader notices that she projects her phobia into the "mirror, which towered menacingly above..." (2). And as she reads AMES TELEGRAPH's analysis on each of the major candidates for the Aguoka House of Assembly, Tina learns that her husband does not stand a chance of winning because, "How can he talk of OMENANAISM to the people when he has a white wife" (8)? Tina, who can no longer think straight because of her phobia, accuses him of conspiring "with the AMES TELEGRAPH to libel me. You definitely want me out of the way"(13). As she reads the article, the narrator says, "a heavy ray had been treacherously let over the full face of the sky and nothingness was left of the, as yet, embryonic radiance that was the tropical high noon" (9). The last straw which breaks the camel's back is her husband giving the money he 
wants to use and buy a car for her to his father to buy a car. Tina who believes she has made genuine sacrifices for their marriage to survive tells him, "I presume you don't have any further use of me, she said crying" (155). She suspects he is making deliberate attempts to isolate her from her people by his refusal to honour the invitation from the British Council. He refuses also their going back to England to live as he is determined to become a politician in Aguoka to change his own black world. As he reasons, "The status of the black man meant more than his very own wife" (155-156). Tina checks her marriage against all the indices of a failed marriage, and when they "slept side by side with two big pillows serving as demarcation line" (16), she realizes it is time for her to "pack some of her clothes in a suitcase" (16) and go back to England.

In the End of the Road, Umeasiegbu, like a psychologist or a psychiatrist, portrays the haunting consequences from repressed childhood trauma, which arises from a society's gross emphasis on sexual intercourse. The narrator begins the story in the novel with the tragic death of Amon, Shaga's girlfriend, who died in a fight with her roommate for the total possession of Shaga. The omniscient narrator says from the very beginning of the novel that, "Amon died at 9:47pm, but Shaga did not know of this till 10:05pm. Eighteen long minutes after the death. Yet he had caused it. He stared at the cold body. But he did not cry. All he could do was shout 'Amon! Amon! Amon! Amon! Amon"' (9)!

The narrator ends the story with Amon's death at 9:47pm, with only the warden at Princess Natasha Hall as the only person at the bedside when it happened. Though Amons's last word is to ask for Shaga, "But he was not there. Naturally" (96)! It is obvious that the narrator holds Shaga responsible for Amon's death. However, it is ironical that the facts the novelist presents between the beginning and end of the novel contradict the narrator's assumption, and may render him as being a naive narrator. But the use of the adverb "naturally" to explain 
Shaga's absence may save the narrator's tale and point of view. A close reading of the work reveals that the two roommates - Amon and Ngoo - kill each other in their rivalry to possess Shaga in a stable relationship. Amon's death and Shaga not being there at her bedside, when she gives up the ghost, it is submitted that the writer uses it to underscore the stupidity of the two girls in killing each other over a stable friendship in an environment where there is no stability even in marriage. Umeasiegbu presents a diseased society, where Amon's mother "had once snatched a boyfriend from her" (73), a sick society where her "father moved away to an unknown destination, her mother had never bothered him" (72), a blighted society where a lecturer snatches girlfriends from his students, a deranged society where Professor Etunkobo's wife, who fights with Amon and has a miscarriage, institutes an uncontested divorce proceedings against her husband because she is enraged, and "She could not believe that responsible men and women could dish out such a falsehood in the name of a report" (85).If there is anybody to be blamed for Amon and Ngoo's death, definitely, it is not Shaga, but their environment - the family, the university and the whole Amesi society.

Moreover, Umeasiegbu serially depicts the ghost of the repressed childhood trauma in Amon emerging from the unconscious to distort her sense of reality. Without these scars exerting pressure on her life, she and Ngoo would not have died. She develops a phobic pathological disorder because of her traumatic childhood: knowing she is an unwanted child, the sexual promiscuity of her parents and other members of her society, a father who abandons them without provision, Prof. Etunkobo's desertion of his wife without any warning, and the fact that his "pay check belonged not to him or his wife, but Amon" (83). She, therefore, feels threatened and her sense of 
phobia and insecurity overwhelms her judgement when her room-mate snatches Shaga from her. She cannot let go without a fight. Shaga she desires, lays a siege for and captures him. She cannot also easily let go of Shaga, whom she prefers over Isidore Isiagu, who has a string of girls, to Shaga who "was more masculine, more fun to date, and more handsome" (43). Amon, who wants to cage Shaga ,and keeps him all to herself, feels "she was entitled to her own fun" (43). She sleeps around with no sense of guilt. After their wild party at Isidore's house, he takes Shaga back to his hotel first and drives back to his house with Amon. Her betrayal of Shaga is portrayed by the narrator through the biblical allusion of Peter's betrayal of Christ in, "Somewhere near them, an impatient cockerel was announcing the herald of dawn.... The same cockerel keeping time for them crew again" (35).

Amon's beauty, which makes men to desire her, which makes village urchins to ululate and "made signs suggestive of admiration and possibly lust" (21), which compels Shaga's room-mate to congratulate him and wishes that she is left "alone with me in hell for a week and I shall not complain. No way" (18), which other female students on "campus admired and envy Amon" (57), could not save her from the psychopathological disorder of phobia. Shaga ought not to be blamed for her death, but first and foremost, her traumatic experiences as a child, which as an adult, "Occasionally, she felt hippish. This happened whenever she thought of her own family and the brewing feud between her and her room-mate" (88-89). It is a blighted and beleaguered family where each person pursues his or her own interest, "where one hundred and twenty-two minutes after her admission into the hospital" (96) as she gives up the ghost, neither of her parents is around. It is a family where as she is dying, she neither asks for her mother, Mrs Ruth Jokodola, nor her father, Architect Jokodola. Theirs is portrayed as a house and not a home for their daughter, before her death, "needed the relaxation if she was to 
return to sanity" (88), she knows where to get it: "in Professor Hencock's home" (88).

\section{Conclusion}

It is submitted, therefore, that Rems Umeasiegbu, like other creative writers, has shown an in-depth knowledge of the causes of human behaviour through his portraiture of fictive characters in The Inevitable Aftermath and End of the Road. In these two novels, he presents characters, whose relationship marriage and friendship -collapses because of pressures from their environments. He goes on further, like a psychologist or a psychiatrist, to present the different defence mechanisms the characters appropriate to defend themselves from their environmental stressors. And finally, he probes the minds of the characters to unearth their dysfunctional behaviour, which is the manifestation of various psychopathological disorders. Umeasiegbu has actually proved truthful the statement that "Novelists who go to psychiatrists are paying for what they should be paid for" (Unknown source quoted in Ann. B. Dobie, 2012: 53).

Florence. O. Orabueze is of the Department of English and Literary Studies, Aloysius Orjinta is of the Department of Modern European Languages, both of the University of Nigeria, Nsukka, while Ngozi Ezenwa-Ohaeto is of the Department of English Language and Literature, Nnamdi Azikiwe University, Awka, Nigeria

\section{Works Cited}

Akwanya, Nicholas N. Verbal Structures: Studies in the Nature and Organizational Patterns of Literary Language. $2^{\text {nd }}$ ed. Enugu: Acena Publishers, 2004. 
Language and Habits of Thought. $2^{\text {nd }}$ ed. Enugu: New Generation Books, 2005.

Amodu, Jonah Eneojoh. "Literature as a Mirror of Society: A Literary Analysis of Muhammed Idris' A Mystical Ring”. Awka Journal of English Language and Literary Studies 4.1 (2013): 122-135.

Aristotle. Poetics. Trans. H. Butcher. Pennsylvania: The Pennsylvania State University Press, 2000. Print.

Barker, Martin. The New Racism. London: Junction Books, 1981.

Butler, Gillian \& Freda McManus. Psychology: A Very Short Introduction. Oxford: Oxford University Press, 2008.

Campbell, Jan. "Images of the Real: Reading History and Psychoanalysis in Toni Morrison's Beloved". Women: A Cultural Review 7.2 (1996): 136-149. Routledge. February 10, 2013.Web.

Dobie, Ann B. Theory into Practice: An Introduction to Literary Criticism. $3^{\text {rd }}$ ed. Wadsworth: Cengage Learning, 2012.

Dwyer, J.C. Human Sexuality: A Christian View. Kansas City: Sheed and Ward, 1987.

Ellison, Ralph. "Richard Wright's Blues". Antioch Review Anthology. Ed. Paul Bixter. New York: World Publishing Co. Ltd, 1953.

Enemo, Ifeoma. P. "Medical Negligence: Liability of Healthcare Providers and Hospitals". Nigerian Juridical Review 10 (2011-2012): 112-131.

Everett, Julin. "Must La Victime Be Feminine? Postcolonial Violence, Gender Ambiguity, and Homoerotic Desire in Sony Labou Tansi's Je soussigne cardiaque". Research in African Literature 44.1 (2013): 1-18.

Feldman, Robert. The Essentials for Understanding Psychology. Massachusetts: Massachusetts University Press, 2000. 
Goring, Paul, et al. Studying Literature. $2^{\text {nd }}$ ed. New York: Bloombury Publishing, 2010.

Ilesanmi, T.M. "The Significance of the Myths of Women in Socio-Political Role-Sharing Among Yoruba People". Gender Perception and Development in Africa - a Socio-Cultural Approach. Lagos. Arrabon Academic Press, 1998.

Kluckhohn, Clyde. The Mirror of Man. New York: McGrawHill, 1949.

McGuffin, H. "Nature and Nurture". Encyclopaedia of Psychology. Ed. J. Thapar. New York: Random House, 1998.

Mkhize, J. "Social Realism in Alex La Guma's Longer Fiction". Dissertation of the University of Natal, 1998.

Mowbray, R. M \& T.F. Rodger. Psychology in Relation to Medicine. Edinburgh: English Language Book Society, 1970.

Myers, D.G. Psychology. New York: Worth Publishers, 1989.

Nnoli, Leo. "The Role of History and Culture in Promoting Good Governance". The Humanities and Good Governance. Eds. A.B.C. Chiegboka, et al. Nimo, Anambra: Rex Charles and Patrick Ltd, 2012. 246-253.

Ogundipe-Leslie, Molora. Recreating Omsehes: African Women and Critical Transformations. Trenton, N.J: Africa World Press, 1994.

Onunkwo, Chibuzo. "Otherness of Literature". Madonna Journal of English and Literary Studies 1 (2009): 4046.

Onwuegbuchunam, Marcellus \& Loyce Okoye. "Gender Equality in the Dispensation of Democratic Governance". The Humanities and Good Governance. Eds. A.B.C. Chiegboka, et al. Nimo, Anambra: Rex and Charles Patrick Ltd, 2012. 795-801. 
Osborn, Reuben. Marxism and Psychoanalysis. New York: Dell Publishing Co., 1965.

Ricoeur, Paul. "Wonder, eroticism and enigma". Cross Currents 14 (1964): 136-137.

Scarr, S. "Developmental Theories for the 1990s: Development and Individual Differences". Child Development 63 (1992). 1-19.

Skinner, B.F. Upon Further Reflections. New Jersey: PrenticeHall, 1997.

Smith, Ronald E. Psychology. Minnesota West Publishing Co., 1993.

Soyinka, Wole. Six Plays. Ibadan: Spectrum Books Ltd., 1998.

Tylor, E.B. Primitive Culture. Vol.2. New York: Harper and Row, 1958.

Udeozo, B.O.S. \& K.L. Nwadialor. "Good Governance and Effective Human Relations: Pathways to Fostering Ethno-Religious Harmony in Nigeria". The Humanities and Good Governance. Eds. A.B.C. Chiegoka, et al. Nimo, Anambra: Rex Charles and Patrick Ltd., 2012. 238-245.

Umeasiegbu, Rems. N. The Inevitable Aftermath. Enugu: Cecta Ltd., 1994.

End of the Road. Enugu: Cecta Ltd., 1986.

Uwasomba, Chijioke. "Flora Nwapa and the Burden of the

Nigerian Woman". Madonna Journal of English and Literary Studies 1 (2009): 124-132.

Watson, John B. Behaviourism. New York: People's Institute, 1924.

William, David T. "Toward the Sociology of White Racism". Racism. Eds. Martin Bulmer and John Solomon. Oxford: Oxford University Press, 1999. 90-101.

Williams, Raymond. Culture. London: Fontana, 1981. 